\title{
РОЗВИТОК РЕЛІГІЙНОГО ТУРИЗМУ ЯК ШЛЯХ ДО ВІДНОВЛЕННЯ ТУРИСТИЧНОЇ ГАЛУЗІ В УМОВАХ СОЦІАЛЬНО- ЕКОНОМЧНОЇ КРИЗИ
}

\author{
Чередниченко А.О., к.е.н., ст. викладач (ХНУМГім. О.М. Бекетова)
}

В статті встановлено, щзо загострення глобальних $і$ регіональних негативних проявів сочіально-економічного та сочіально-політичного характеру відбивається на розвиток туристичної галузі. Таким чином назріла необхідність впровадження нових напрямків туристичної діяльності, розробки та впровадження нового якісного туристичного продукту. Запропоновано розглянути в иьому контексті такий вид туризму як релігійний туризм. Визначені основні шляхи його розвитку України. Відпрацьовано рекомендації щзодо його розвитку в сучасних умовах.

Ключові слова: релісійний туризм, паломництво, святі місця, культові споруди, туристичний продукт, екскурсійні поӥздки.

\section{РАЗВИТИЕ РЕЛИГИОЗНОГО ТУРИЗМА КАК ПУТЬ К ВОССТАНОВЛЕНИЕ ТУРИЗМА В УСЛОВИЯХ СОЦИАЛЬНО- ЕКОНОМЧНИХ КРИЗИСА}

\section{Чередниченко А.А., к.э.н., ст. преподаватель (ХНУГХ им. А.Н. Бекетова)}

В статье установлено, что обострение глобальных и региональных негативных проявлений сочиально-экономического и сочиально-политического характера отражается на развитие туристической отрасли. Таким образом назрела необходимость внедрения новых направлений туристической деятельности, разработки и внедрения нового качественного туристического продукта. Предложено рассмотреть в этом контексте такой вид туризма как религиозный туризм. Определены основные пути его развития Украины. Отработаны рекомендации по его развитию в современных условиях.

Ключевые слова: религиозный, паломнический туризм, святые места, культовые сооружения, туристический продукт, экскурсионные поездки.

\section{DEVELOPMENT OF RELIGIOUS TOURISM AS A WAY TO RESTORE THE TOURISM INDUSTRY IN TERMS OF SOCIO-EKONOMCHNOYI CRISIS}

\author{
Cherednychenko A.O., Candidate of Economic Sciences, p. teacher \\ (O. M. Beketov National University of Urban Economy)
}

The paper established that the aggravation of global and regional negative effects of socio-economic and socio-political development affects the tourism industry. Ukraine has great potential for development of religious tourism. However, many recognize that this potential remains unrealized. The reasons may be poor infrastructure; lack of information

(C) Чередниченко А.О. $\quad$ Вісник економіки транспорту і промисловості № 58, 2017 
about available resources and routes; while weak links with between travel agencies and religious organizations; shortage in this area qualified personnel. Thus there is a need of introducing new tourism activities, development and implementation of new quality tourist product. Proposed to be considered in this context, this kind of tourism like religious tourism. The main ways of development of Ukraine. Developed recommendations for its development in modern conditions.

Keywords: religious, pilgrimage tourism, Holy places, places of worship, tourist attraction, excursions.

Постановка проблеми та ї̈ зв'язки з науковими чи практичними завданнями.

В сучасних умовах фінансовоекономічної і соціальної кризи туристична галузь потребує пошуку нових шляхів відновлення втрачених позицій. $\mathrm{XX}$ століття це той період часу коли бурхливо розвивалася індустрія туризму, удосконалювалися транспортні засоби та засоби зв'язку. У другій його половині окремі традиційні форми туризму почали втрачати актуальність та вже не задовольняли потреби туристів.

Безліч культових споруд було перепрофільована під музеї, концертні зали та інше, отже вони виступали не як об'єкти поклоніння, а як об'єкти туризму.

Нині зміст і призначення багатьох культових об'єктів набуває свого первинного сенсу, вони стають об'єктами поклоніння і об'єктами пізнання. Релігійні цінності - це частина культурної спадщини і об'єкти туризму одночасно. Слід зазначити що, релігійний туризм грає велику роль у системі як міжнародного так i внутрішнього туризму. Люди вирушають у паломництво і екскурсійні поїздки по святих місцях і до релігійних центрів. Вони прагнуть брати участь у релігійних церемоніях, помолитися, зробити жертвопринесення. Отже, релігія впливає на формування самосвідомості і стереотипів поведінки людей.

Аналіз досліджень $і$ публікацій. Розглядом вказаної проблеми займаються такі вчені як Дмитриевський А.В., Любіцева О.О., Романчук С.П., Маїло Я.В., Христов Т.Т., Биржаков М.Б., Сенін
В.С., Муравйов О.Н., Романчук С.П., Павлов С.В., Мезенцев К.В. [1-9].

Виділення невирімених частин загальної проблеми.

Незважаючи на значну кількість досліджень, публікацій та наукових праць 3 проблем туризму та туристичної галузі існує безліч проблемних питань. Питання розвитку та перспективи релігійного туризму $є$ невід'ємною частиною туристичної галузі. Невирішеними питанням $\epsilon$ популяризація релігійного туризму, розробка тур пакетів, ведення обліку туристів релігійних турів.

Mema cmammi. Основна мета даного дослідження полягає у визначенні проблемних питань, особливостей організації та перспектив розвитку релігійного туризму (основних його різновидів) як в Україні так і за ії межами.

$\begin{array}{ccr}\text { Виклад } & \text { основного } & \text { матеріалу } \\ \text { дослідження. } & \text { Релігійний } & \text { туризм } \\ \text { вважається } & \text { історично першим } & \text { видом }\end{array}$ туристичних подорожей, що може бути віднесений до періоду формування світових релігій. Релігійний туризм - це самостійний вид туризму, який $\epsilon$ складовою сучасної індустрії туризму У релігійному туризмі прийнято виокремлювати два напрями діяльності релігійний, пов'язаний з участю у подіях релігійного життя, що здійснюють за допомогою екскурсій, і паломницький, як подорож з метою відвідування святинь і святих місць.

Поняття «релігійний туризм», як правило, використовується як синонім терміна «паломництво». У широкому сенсі це допустимо. А у вузькому сенсі паломництвом вважається відвідування 
головних святинь даної конфесії в строго певний час $\mathrm{i} 3$ дотриманням режиму перебування, чим підкреслюється елітність паломництва по відношенню до інших форм релігійного туризму. Наприклад, у православ'ї паломництвом називають тільки відвідування Святої Землі протягом не менше 10 днів. Всі інші релігійні поїздки визначаються терміном «прощу». У мусульман відвідання Мекки може бути визнано хаджем тільки в тому випадку, якщо було здійснено у місяці зуль-хіджа під час свята Ід аль-адха. Інші культові поїздки, і не тільки в Мекку, називають «умра» [1]

Серед віруючих в Україні домінують християни (95\%), з яких 54,5\% православні та 18,6\% католики. [2]

\section{Основна} відмінність паломницького туризму від релігійного туризму полягає у тому, що паломників, цікавить особиста участь у релігійних культах. Під паломництвом можна розуміти мандрівку людей для поклоніння до святих місць. Відвідування екскурсій, музеїв, виставок для них вторинне та загалом мало цікаве. Тоді як для релігійних туристів об'єктами відвідування є місця та центри релігій. Такі поїдки можуть бути зумовлені культовими актами, святами, фестивалями, що відбуваються у конкретний період року.

Паломницькі тури на відміну від релігійно-пізнавальних чи культурноісторичних, несуть певний віруванням сенс скоєння обряду, тобто не тільки пізнавальну мету. Паломники переважно дбають про релігію, про святі місця до яких вони приїхали. У цих турах істотно скорочено розважальний розділ програми, хоча оздоровчий i пізнавальний відпочинок як таке не заперечується. Паломники зазвичай висувають набагато менше вимог до рівня i якістю обслуговування, харчування, розміщення, ніж інші мандрівники. Вони зупиняються ночувати в келіях монастирів, біля храмів, в наметових містечках (наприклад, під час хаджу), можуть відпочивати в храмах на підлозі або безпосередньо надворі. При цьому вибір їжі у паломників невеликий i не вибагливий. Паломники мають можливість поспілкуватися 3 релігійними особами (наприклад, 3 монахами монастирів), знайти тут собі духівників.

Паломництво відіграє важливу загальноосвітню роль. Так, монастирі й храми в Україні завжди, були як місцем духовного продукування, так й культурними центрами. Століттями накопичувалися книжки, ікони, твори прикладного мистецтва, вироби народних промислів. Монастирські і храмові будинки збудовані до 18 століття були головними архітектурними пам'ятниками своєї епохи. Тому, паломництво дає чудову можливість ознайомитися 3 історією, архітектурою, іконописом, ремісничими традиціями України, а це вже цікаво і світським туристам.

До популярних православних центрів світу належать:

- свята гора Афон (Греція);

- храм святого Лазаря 3 його гробницею і мощами (Кіпр);

- монастир Сопочани із діючою церквою Святої Трійці та фресками XIII ст. (Сербія);

- церква Святої Софії, собор О. Невського і церква Святого Пантейлемона (Болгарія);

- Сіонський собор, храм Метехі, Монастир Святого Давида (Тбілісі), храм Светі-Цховелі та монастир Гелаті (Мцхета) у Грузії;

- Києво-Печерська лавра (м. Київ, Україна);

- Почаївська Лавра (м. Почаїв, Україна);

- Олександро-Невська, ТроїцькоСергіївська (Росія) та ін. Католицизм найчисленніший напрям у християнстві.

Для католиків i протестантів найбільшими сакральними реліквіями є: Істинний Хрест (Рим), Свята Кров (Брюгге, Бельгія), Терновий Вінець, Собор Паризької Богоматері (Париж, Франція), 
Лурд (Франція), Туринська плащаниця (Турин, Італія), Святі Цвяхи (Ітонський коледж, Велика Британія), Ченстохово (Польща) тощо. Відомий центр паломництва буддистів - м. Бодхгая (Індія). Тут Далайлама щорічно читає лекції. У м. Дхармаса-ла (Індія) розташована сучасна резиденція Далайлами - буддистів Тибету й уряду тибетського у вигнанні. Важлива святиня ісламу - мечеть Хайфа Омара в Срусалимі, що $\epsilon$ третьою за значущістю $\mathrm{y}$ мусульманському світі.

На українському ринку туризму вже сформовані туристичні структури (фірми, агенції), які займаються практичної організацією поїздок як прочан так і екскурсантів, і які спеціалізуються на наданні послуг у сфері релігійного туризму. Організацією переважної більшості турів для прочан традиційно займалися структури, які діють при паломницьких відділах єпархій (це стосується християнських релігійних конфесій) та аналогічних структур інших релігійних конфесій (ісламської, буддійської та іншої направленості). Як правило для організації таких турів необхідно отримати дозвіл (благословення).

У цілому в Україні нараховується близько 130 паломницьких відділів, служб, агентств, фірм. Географія пропонованих ними маршрутів охоплює всю територію України та усі країни Європи і Близького Сходу. У середньому одна така служба пропонує за рік приблизно 50 поїздок. Визначити кількість внутрішніх релігійних туристів не $\epsilon$ можливим. Якщо припустити, що усі активні віруючі здійснюють туристичні поїздки тільки з релігійними цілями, то їх частка у загальному туристичному потоці займає від $8,5 \%$ до $20 \%$. Тоді на релігійний туризм припадає від 160 до 360 тисяч організованих поїздок i екскурсій, 3 яких 120 - 300 тис. зарубіжні, і лише 25-60 тисяч - внутрішні. Виходить, що в Україні частка релігійного туризму в загальному туристичному потоці навряд перевищує 8-10\%, але швидше за все - вона нижча. Тобто, рівень розвитку релігійного туризму в Україні як мінімум в два рази нижче, ніж у середньому в світі. Кількість іноземних паломників в Україну складає в середньому 60-70 тисяч, релігійнопізнавальних іноземних туристів приблизно стільки ж. 3 них дві третини складають ізраїльтяни, російських паломників не більше $15 \%$ (8- 10 тисяч паломників). За даними місцевих спостережень у 2015 році кількість релігійних туристів у Львові склала близько 700 тис. осіб, у Києві - близько 600 тис. осіб,у Почаєві - не більше 500 тисяч, у Зарваниці - до 500 тисяч, у Джублику - до 300 тисяч, у Святогірську близько 100 тисяч. [8]

До основних причин, що перешкоджає розвитку релігійного туризму, належать:

- відсутність комплексної програми розвитку релігійного туризму;

інфраструктури;

- недостатня кількість готельних місць i невідповідність їх структурі попиту;

$$
\text { відсутність належного }
$$

громадського порядку в місцях здійснення паломництва;

відсутність рекламноінформаційної продукції, пропаганди та просування релігійного туризму;

- відсутність системи управління релігійним туризмом [3].

На сьогоднішньому ринку релігійного туризму існує небагато підприємств, які працюють 3 настільки специфічним турпродуктом i усвідомлюють всі його тонкощі. Для успішної організації туризму в духовних центрах потрібна співпраця туристичних підприємств 3 діячами церкви.

3 точки зору туристських центрів релігійному туризму близький, так званий, науковий туризм релігійної тематики. Такі 
поїздки малочисельні, але вони розширюють географію туристських поїздок. Вчених цікавить релігійна спадщина - рукописи, різні культові предмети, археологічні розкопки, архітектурні форми, минуле релігій й багато іншого.

На теперішній час, в індустрії релігійного туризму можна визначити чотири складові: релігійні об'єкти, розміщення, харчування, транспорт.

Туристи, які вирушають у паломницьку чи екскурсійну поїздку, використовують різні засоби транспорту задля досягнення пункту (пунктів) прибуття. Це авіаційний, залізничний, автомобільний (автобусний), водний транспорт. У паломництві практикуються піші переміщення за визначеними маршрутами, від одного пункту до іншого.

Вищезазначене потребує значних зусиль 3 розробки туристського продукту, тобто створення умов та організація подорожей $\epsilon$ вкрай ускладненим процесом. Створення турпродукту звичайно починається із висування ідеї, й прийняття рішень розробити туристичний пакет (туристичний пакет - комплекс послуг iз розміщення, перевезенні, харчування релігійних туристів, послуги гідів, перекладачів та інші). Після прийняття рішення про створення туру (туристичного пакету), йдуть узагальнення кількох етапів розробки тур продукту:

- вивчення попиту на туристському ринку й визначення базових складових туру; політика);

- розрахунок вартості туру (цінова

- продаж (реалізація) туру, тобто просування його на ринок.

На початку відбувається створення концепції туру, вивчення основних тенденцій як в паломницькому туризмі так i в екскурсійному туризмі релігійної тематики. Вивчення якісно - кількісних характеристик туру: вид транспорту, наявність коштів на розміщення, пункти харчування, об'єкти екскурсійного показу, культові споруди тощо. Поруч із попитом досліджується також пропозиція щодо пошуку та відбору для майбутнього туру первинних туристських послуг та його виробників і постачальників. Вивчаються релігійні центри, у яких прибудуть туристи. Важливі їх транспортна доступність, ступінь розвиненості інфраструктури, якість послуг тощо. При практичної організації паломницьких поїздок досліджуються особливості проведення культових заходів, а саме можливість прийняти в храмах, монастирях тощо. Під час створення туру важливо враховувати всі нюанси. Наприклад, окремі чоловічі православні монастирі приймають лише паломниківчоловіків тощо. У деякі індуські храми в Індії (чи його частини) пускають лише індусів, а Духовні Вчителі можуть бути відсутні у якийсь час року. У Мекку не дозволено в'їзд не мусульманам.

Коли завершено вивчення попиту й пропозиції на ринку складається вербальна модель (робочий проект) туру. Туроператор вибирає контрагентів, встановлює із ними контакт й починає переговори. Потім здійснюється просування турпродукту на туристському ринку. Створення системи заходів, спрямованої на попит й стимулювання збуту туристських послуг (збільшення продажів).

Проаналізувавши перспективи розвитку релігійного туризму в Україні можна дійти наступного висновку.

Нині у світі дедалі більше розвиток одержують різноманітні види пізнавального, зокрема i релігійного туризму. Маршрути поїздок віруючих різних конфесій склали таки країни як Ізраїль, Греція, Єгипет, Йорданія, Туреччина, Італія, Індія, Саудівська Аравія, Китайський Тібет та інші місця, що мають релігійну значимість. Проте існуючий сьогодні рівень підготовки подібних маршрутів вітчизняними турфірмами, їх супровід, відповідність 
організації та прийому положенням різних віросповідань ще не відповідають необхідними вимогами. Більшість українських фірм, які проводять роботу, не мають підтримки i благословення церкви. Вартість запропонованих поїздок у закордонні країни перевищує можливості більшості громадян країни.

Крім зазначених невирішених питань виїзного релігійного туризму, недостатньо опрацьованим $є$ механізм залучення іноземних туристів до українських святинь, які мають значний конфесійний і культурне інтерес.

Враховуючи кризи у галузі туризму доцільним $є$ розвиток цього сегменту, але на комплексній, програмній основі та за підтримка Міністерства інфраструктури, Міністерства культури, Міністерства освіти та науки та інших міністерств та відомств, банківських установ, вітчизняних та іноземних інвесторів. Особливу увагу передбачається приділити організації в'їзного релігійного туризму. Це дозволить інвестувати в українську економіку.

Найважливішим елементом реалізації цієї програми, безумовно, має бути його рекламно-інформаційний супровід: пропаганда через пресу, радіо і телебачення, випуск книжок про храмах, духовних пам'ятниках України, відеофільмів. Доцільним $є$ проведення ряду безоплатних рекламноінформаційних поїздок, участь у них діячів різних конфесій, журналістів, представників турагентств, кількох відомих і авторитетних осіб.

Визначити фактичну кількість релігійних туристів i екскурсантів в Україні неможливо, оскільки з цього виду туризму відсутні як статистика, так i аналітичні дослідження. В державному статистичному бюлетені 3 туризму враховуються лише організовані туристи i екскурсанти, які оформили путівки в українських тур агентствах. Самодіяльні ж туристи і екскурсійні бюро в облік не потрапляють.

Висновки. В ході вирішення вищенаведених проблем можна зробити висновок: Україна володіє величезною культурною та природньою спадщиною, зокрема й у релігійному туризмі. Багато пам'яток релігійної спрямованості використовувалося в туризмі й раніше, розроблені популярні туристичні маршрути, але вони не зовсім відповідають світовим стандартам. В останні роки відмічається зростання зацікавленості туристів саме до цього сегменту туристичного ринку. Тому треба ефективно використати можливості.

Україна має великий потенціал розвитку релігійного туризму. Проте багато хто визнає, що це потенціал залишається нереалізованим. Серед причин може бути нерозвинена інфраструктура; дефіцит інформації про наявні ресурси i маршрути; слабкі поки що зв'язки 3 між туристичними фірмами i релігійними організаціями; брак у цій сфері кваліфікованих кадрів.

Тільки спільно паломницькі служби й туристські організації, за підтримки державних інституцій зможуть відродити, зберегти й упорядкувати об'єкти культури, визначні пам'ятки, місця паломництва, облаштувати їх і створити навколо них належний статок, культурне середовище проживання і комфортність

\section{ПЕРЕЛІК ВИКОРИСТАНИХ ДЖЕРЕЛ}

1. Дмитриевский

Религиеведение для туристического бизнеса: практиче-ские аспекты: учебное пособие / А.В. Дмитриевский. - Донецк: Донецкий ин-т туристического бизнеса, 2004. - 306 с.
2. Любіцева
O.O.
Напрямки

розвитку релігійного туризму в Україні / О.О. Любіцева, С.П. Романчук // Туризм у XXI столітті: глобальні тенденції i регіональні особливості: матеріали Міжнар. наук.-практ. конф. (10-11 жовтня 2001 р., м. Київ). - К.: Знання України, 2002. - C. 61-65. 
3. Маїло Я.В. Проблеми розвитку релігійного туризму в Україні // Я.В. Маїло / Студентська наука в новому тисячолітті: сучасні проблеми громадського харчування, готельного господарства та туризму: матеріали Всеукр. студентської наук. конф. (19-21 квітня 2000 р., м. Київ). - К.: Київський держ. торговельно-економічний ун-т, 2000. - C. 119-121.

4. Христов Т.Т Релігійний туризм: навчальних посібників / Т.Т. Христов. М.: Академія, 2005 - 288 с.

5. Биржаков М.Б. Паломницький i релігійний туризм: довідник / М.Б. Биржаков. - СПб.: ОЛБИС, 1997. - 732 с.
6. Сенин В.С. Организация международного туризма: Учебник / В.С. Сенин. - 2-е., перераб. и доп. - М.: Финанси и статистика, 2003. - 400 с.

7. Муравьев А.Н. Путешествие по святым местам, [Текст] учебное пособие/ А.Н.Муравьев - М.: «Книга» 1990- 350с.

8. Павлов С.В. Географія релігій: навчальний посібник / С.В. Павлов, К.В. Мезенцев, О.О. Любіцева. - К.: АртЕК, 1998. - $504 \mathrm{c}$.

9. Романчук С.П. Паломництво українців до Святої Землі. Історикогеографічний нарис / С.П. Романчук // Географія та основи економіки в школі. 2000. - №1. - C. 11-14. 